А.С. Зіневич,

аспірант Інституту філософії імені Г.С. Сковороди НАН України

\title{
ФЕНОМЕНОЛОГІЯ Й ОНТОЛОГІЯ А.БЕРГСОНА ЯК ДЖЕРЕЛО ЕКЗИСТЕНЦІАЛЬНОӤ ФІЛОСОФІЇ Г.МАРСЕЛЯ Й Є.МІНКОВСКОГО
}

Незважаючи на те, що чимало дослідників (зокрема, Е.Мунье, О.Больнов, Г.-Г.Гадамер, П.Рікер, В.Барретт, М.Вето, Г.Шпігельберг, В.В.Лях та ін.) визнають вплив філософії життя, особливо бергсонівської, на становлення екзистенціальної філософії, основним джерелом iі вважається феноменологія Гуссерля, від якої М.Гайдегер зробить свій онтологічний поворот. Інших екзистенціальних філософів розглядають як послідовників Гайдегера. Виходить, екзистенціальна філософія переважно мислиться як єдина традиція, що корениться у феноменології Гуссерля. Те саме і з французькою екзистенціальною філософією: ії пов'язують із послідовниками Гуссерля й Гайдегеpa, a саме - Ж.-П. Сартром, С. де Бувуар і М.Мерло-Понті. Таким чином ігнорується, замовчується інша традиція екзистенціальної філософії, що склалася задовго до відкриття Гуссерля у Франції, яке почалося з його «Паризьких доповідей» 1929 р., і публікації їх переробленого варіанту під назвою «Картезіанські медитації» у перекладі Е.Левінаса й Г.Пфейфер у 1931 р. Спробуємо дослідити шлях Бергсона від розробленої ним оригінальної феноменології до онтології, позначивши розбіжності з позицією Гуссерля. I доведемо, що поряд із гуссерліанською галуззю існує бергсоніанська галузь екзистенціальної філософії, яка представлена Г.Марселем і Є.Мінковським.

Існує думка, що Бергсон, незважаючи на значну популярність у 1900-1930 роках, не залишив учнів й того, що можна було б назвати «бергсоніанською школою». Справді, мало хто з учнів майстра називає себе бергсоніанцем. Тому Євгеній Мінковський скоріше виключення із правила, коли погоджується з думкою колег, начебто «він більший бергсоніанець, ніж сам Бергсон» [19, 193]. По закінченню медичного факультету він мав намір «... залишити медицину через матеріалістичну орієнтацію, що панувала в ній в ту добу». Але, як відзначає дослідник, саме тоді, «... не інакше як через провидіння, у мої руки потрапила праця Бергсона, що мала 
вирішальний вплив... це було справжнє одкровення й моя пам'ять про це така жива, начебто це трапилося тільки вчора» $[19,193]$ (Пер. 3 фр. мій. - Автор статmi). Так описує Мінковський зустріч з Бергсоном, що стала вирішальним моментом його життя. По поверненню 3 фронтів Першої світової війни (на яку він добровольцем відправився зі Швейцарії в якості лікаря) Є.Мінковський захистить й опублікує дисертаційні тези «Поняття втрати життєвого контакту з реальністю і його застосування в психопатології» («La notion de perte de contact vital avec la réalité et ses applications en psychopathologie», Paris, 1926). За нею вийде його основна екзістенціально-феноменологічна праця «Життевий час» («Le temps vecu», 1933). За його словами, у своїй концепції «життєвого часу» (дослівно: «час, що проживається») він успадковує концепцію «чистої тривалості» Бергсона $[19,192]$. Однак те, що Мінковський був «піонером феноменологічної психіатрії» [див.: 13] і називав свій метод «феноменологічним», уведе більшість дослідників французької феноменології в оману. Феноменологи (М.Мерло-Понті, А.-Т. Тименецька, Е.ван Дорцен, Б.Ванденфельс) та дослідники (І.Блауберг, В.П.Візгін, О.А.Власова) розглядатимуть його феноменологію як «синтез ідей Бергсона і Гуссерля». I тільки Шпігельберг вкаже на його феноменологію як на бергсоніанську: «... головне джерело його натхнення - від Бергсона. Гуссерль згадується тільки між іншим. Також він визнає вплив лише від Шелера, але, не зважаючи на багато паралелей, не Гайдегера» [20, 434] (Пер. $з$ англ. Мій. - Автор статmі.). На думку Мінковського, основою його філософії стала феноменологія, розроблена Бергсоном у «Досвіді про безпосередні дані свідомості». За його твердженням, розробка темпоральної проблематики як життя-вчасі передувало його знайомству з «Буттям і часом» Гайдегера. Як бачимо, сама феноменологічна традиція, яка вважається джерелом екзистенціальної, зовсім не є однорідною.

Г.Марсель також визнає своє учнівство в Бергсона й навіть присвятить йому свій перший «Метафізичний щоденник»: «Саме Бергсону я зобов' язаний своїм звільненням від духу абстрактності, згубність якого я повинен був значно пізніше розкрити» $[15,81]$. У 1933 р. Марсель пише в щоденнику замітки, які переростуть у «Нарис феноменології володіння». Але це не має ввести нас в оману: 3 феноменологією Гуссерля Марсель познайомиться тільки в 1928 р. (це засвідчує його запис у «Метафізичному щоденнику»). У «Філософському заповіті» (1968) Марсель пояснює: «... я постійно звертався 
до феноменологічного методу, ніяк не пов'язаному з Гуссерлем, запитуючи, звісно, про можливість певних привілейованих видів досвіду» $[9,305]$. Це дає підставу твердити про його феноменологію як розвинуту незалежно від феноменології Гуссерля. Підтвердження нашого висновку ми знайшли в Шпігельберга, який цитує французького феноменолога Жана Херінга: «Ми вважаємо можливим стверджувати, що навіть якби німецька феноменологія залишалася невідомою у Франції (якщо припустити неможливе), вона, проте, була б створена - і це здійснилося б значною мірою завдяки впливу Габриеля Марселя» [20, 448] (Пер. 3 англ. мій. - Автор статmі). Також Ванденфельс називає Марселя «попередником феноменології» у Франції $[3,50]$, який, за П.Рікером, створив один із трьох варіантів французької феноменології (поряд із Сартром та Мерло-Понті) $[3,50]$. «Метафізичний щоденник», який Марсель вів у роки Першої світової війни (точніше з 1913 по 1923 рр), вийшов у світ в 1927 р., в один рік 3 «Буттям і часом» М.Гайдегера. Однак, окрім учня Марселя й Гуссерля Поля Рікера, майже ніхто не підкреслює появу онтологічної проблематики в Марселя до видання Сартром «Буття і ніщо». Отже, сам термін «феноменологія» у працях Е.Мінковського й Г.Марселя означає звертання не до гуссерліанської феноменології, а до феномена конкретної людської особистості, розглянутої в єдності її свідомості, тіла, почуттів й образу життя.

Гайдегер у своїх «Пролегоменах до історії поняття часу» помилково визначає витоком бергсонівської філософії «ідеї Брентанівської психології» $[12,27]$, що вплинули на Бергсона через Вільяма Джемса. Однак, як відзначають і Джемс, і Бергсон, ідеї «потоку» вони дійшли незалежно один від одного. Коли ж відбулася їхня зустріч, обидва філософи були вражені синхронністю розвитку їх філософій.

Вважаємо, що крім безпосередніх учителів Бергсона - Равессона й Бутру, які продовжували традицію спіритуалізму Мен де Бірана, бергсонівська філософія має своїм витоком філософію Паскаля. Бергсон вирізняв Декарта й Паскаля як родоначальників двох традицій мислення. Якщо «картезіанство є філософією «ясних та чітких» ідей», яка «не визнавала іншого, ніж очевидність (l'evidence), критерію істини» $[1,345-346]$, то запропонована Паскалем традиція сентименталізму (де сентимент розуміється як інтуїтивне пізнання) «визнає первинність не просто раціонального розуму (la pure raison), але «розуму витонченого» («l'esprit de finesse»), за допомогою якого стає можливим доповнювати та виправляти в судженнях те, що $є$ 
результатом діяльності «розуму геометричного»«, але «не дорівнює містичному спогляданню, оскільки іiі результати піддаються об’єктивному контролю та перевірці» [1, 345-346]. Бергсон продовжив цю саму лінію розрізнення, говорячи про пізнання статичне, за допомогою понять, і динамічне, через безпосередню інтуїцію. I якщо першому доступний лише роздроблений на фрагменти світ, яким він даний спостерігачеві «ззовні», то інтуїція схоплює свій об'єкт зсередини - у його цілісності.

Сучасний дослідник Бергсона Ф.Вормс зауважує: «Кожний момент в історії французької філософії визначається скоріше не добутком одного якогось автора, а опозицією між двома добутками, двома стилями ... Декарт і Паскаль, Руссо й Вольтер, Конт і Мен де Біран» [4, 189-190]. Якщо виходити з опозиції «Декарт-Паскаль», то стає зрозуміло, що Гуссерль продовжує гносеологічну традицію «школи підозри» Декарта в XX столітті, тоді як Бергсон - традицію «філософії довіри» Паскаля. Отже, опозиція Декарт-Паскаль переростає в опозицію Бергсон-Гуссерль. Немає в XX столітті двох більш далеких, але й більш близьких філософів. Інакше Гуссерль не викликнув би після лекції А.Койре про бергсонівську філософію: «Ми справжні бергсоніанці!». А Гайдегер не пов'язував би появу проблематики часу в Гуссерля з його знайомством із філософією Бергсона. Але зараз важливо прояснити принципові відмінності їх позицій.

Гуссерль і Бергсон: гносеологія й онтологія. Філософію Бергсона, як і Гуссерля, можна умовно поділити на три періоди. У Бергсона це: феноменологія, онтологія й етика. На запитання «чи був Бергсон - феноменологом?», Мінковський відповідає: «Звичайно, ні, якщо брати його праці в цілому. Тоді як, якщо брати «Безпосередні дані свідомості», - це феноменологія. А «Матерія й пам'ять» і «Творча еволюція» - вже ні» $[19,192]$ (Пер. 3 фр. мій. - Автор cmammi). Отже, можна твердити, що філософія Бергсона була феноменологією за суттю, а не за назвою. У своїй феноменології Гуссерль і Бергсон критикували «природничо-науковий розум», що не досягає реальності, - але 3 двох різних боків.

Гуссерль підійшов до проблеми з боку самого Ratio - розвінчуючи «наївність» природничої установки, немов очищаючи свідомість від наївно засвоєних, невідрефлектованих концептів. Його мета - добратися до істини як повноти знання «остаточної очевидності». I вирішував він гносеологічне завдання, а саме: в який спосіб, редукуючи природничу установку, досягти більшої об' єктивності, ніж та штучна, 
що виникає замість реального світу. Засіб же досягнення цієї мети застосування свідомістю вдосконаленої методології.

Бергсон, який спочатку дотримувався схожих ідей у «Безпосередніх даних свідомості», потім здійснює поворот до життєвого потоку, вирішуючи проблему з боку самого життя, або буття. Тобто, вирішує завдання: як досягти повноти реальності як живої тривалості, «реальності, що триває внутрішньо, реальності, що є самою тривалістю» [2, 279]. Тому завдання, поставленє ним у «Матерії й пам'яті», «Введенні в метафізику» і «Творчої еволюції», $є$ вже не гносеологічним, а онтологічним. В.В.Лях убачає у звертанні Бергсона до джерела, що стоїть за інтелектом і інстинктом, «прагнення Бергсона онтологізувати гносеологічні проблеми» $[7,48]$. Такий само висновок знаходимо й у М.Мерло-Понті: «Абсолютне знання не парить у просторі, воно завжди комусь притаманне. У 1889 році це було великим відкриттям - яке мало майбутнє - представити основою філософії не «я мислю» 3 його іманентним мисленням, а «само-Буття», що його само-зв'язування водночас $\epsilon$ відривом від себе» $[18,184]$ (Пер. 3 англ. мій. - Автор статmi).

Несимволічна метафізика Бергсона і трансцендентальна філософія Гуссерля. Попри всі розбіжності між онтологією Бергсона і трансцендентальною феноменологією Гуссерля «Ідей» і «Медитацій», їх поєднує ідея «сутності» або «ейдоса», що схоплюється інтуїцією Бергсона й ейдетичною інтуїцією (сутнісним баченням) Гуссерля. Однак, як ми побачимо, розуміння як цієї сутності, так $i$ інтуїтивного способу іï схоплення - докорінно різні. Гуссерль, як i Кант, дійде необхідності розрізнити феномен і ноумен, i за видимим «феноменом» шукати його «ейдос». Звичайно, «ейдос» Гуссерля не $\epsilon$ поняттям: «Він передує всім поняттям, якщо їх розуміти як значення слів, які в якості чистих понять скоріше повинні бути утворені відповідно до нього» $[5,94]$. Однак «ейдос» не припиняє бути «самим загальним».

За Бергсоном, трансцендентним $є$ не абсолютна свідомість і не ейдоси, а саме життя. «Отут ми не обійдемося без того, щоб не приєднатися до глибоких поглядів Бергсона про трансцендентність життя в його відношенні до причин і ідей» $[10,121],-$ коментує Г.Марсель. Цей «світ причин і наслідків» є безжиттєвим світом математичних і логічних формул. На думку Бергсона, життя трансцендентне як формулам, силогізмам, символам й інтерпретаціям, тобто конструкціям нашої свідомості, так і емпіричним сприйняттям даного феномена 
у даний момент часу. Адже феномен, виловлений з ріки становлення й розглянутий поза часом, уже мертвий феномен.

«Потойбіч досвіду» для Канта, як і для Гуссерля розуміється як потойбіч і «зовнішньго досвіду», і «внутрішнього досвіду». «Воно таким чином $\epsilon$ пізнанням apriori, або пізнанням з чистого розсудку й чистого розуму» $[11,10]$. Але, на відміну від Канта, Гуссерль постулює можливість збагнення «речі у собі», або ноумена (сутності), схованого за феноменом (явищем). Можна сказати, що Гуссерль долає «трансцендентність» речі у собі стосовно свідомості, знаходячи iii в самій свідомості. Розв'язок Кантівського трансцендентального питання Гуссерль знаходить у редукції, що продовжує роботу декартівського cogito. У Декарта cogito ставить під сумнів і реальність зовнішнього «протяжного» світу (куди входить реальність тіла мислителя), і реальність та цінність мого воління, почуттів, усього «ірраціонального». Єдине, що залишається безсумнівним, це сама свідомість, що знищує, редукує весь світ навколо, аж до матеріальної, «протяжної» частини себе. У цьому сенсі, якщо редукція Гуссерля була б спрямована на саму цю свідомість, вона могла б «урятувати світ», виявити щось крім установок моєї его-свідомості. Тобто, якщо зрозуміти редукцію як припинення діяльності свідомості, тоді виявляємо навіть «не світ у свідомості», а світ «потойбіч» раціоналізованого штучного простору, спроектованого свідомістю на світ. Світ - це потойбіч Ratio, потойбіч «трансцендентальних обмежень» (Кант). Мабуть, знайдемо потойбіч свідомості й те «живе «Я» (Бергсон, Марсель), яке було усунуто свідомістю, підмінене нею. Це й могло б стати розв'язкою трансцендентального питання Канта про можливість пізнати «річ у собі». Справді, всередині свідомості ми укладені в певні межі, як у капсулу, що не дає нам змоги бачити світ «яким він є». I будь-який вид, що відкривається 3 капсули, зумовлений апріорними конструкціями, тобто призмами, що відокремлюють суб' єкта від світу подібно заслінкам перед очима. I от, якщо зрозуміти редукцію як редукцію саме свідомості (а не світу), ми раптом побачимо ті самі речі у собі, якими вони $є$ по той бік свідомості. Тобто ми заново відкриємо світ... зсередини його самого. Таке розуміння редукції знайдемо у Бергсона. Але навряд чи виявимо таке розуміння в Гуссерля «Ідей» і «Медитацій» - тому, що він доходить твердження «трансцендентального еgо», тобто все-таки залишає лазівку для ототожнення суб'єкта із загальною свідомістю, нібито ще не підозрюючи про можливість іншого я, «екзистенці- 
ального я» або «живого я», залученого в світ, яке будуть обгрунтовувати Марсель і Минковский. За Гуссерлем періоду Ідей, розв'язок «кантівского питання» полягає не в тому, щоб нарешті «залучитися до світу», осягти його зсередини нього самого, яке відкрив для себе Бергсон, а в тому, щоб зайняти ще вищу позицію над світом. Е.Левінас відзначає: «Філософія починається з редукції: це акт, в якому, безперечно, ми розглядаємо життя у всій його конкретності, однак більше не живемо» $[6,137]$. Це в пізніший період Гуссерля «життєвого світу» можна знайти кроки до включення людини в світ. Зіставляючи інтуїцію Гуссерля й Бергсона, Левінас твердить: «... у понятті інтуїиї не йдеться про почуттєве або "безпосереднє», у змісті «даного раніше всяких позитивних кроків розуму»; не йдеться про протиставлення інтуїиї «дискурсу». Йдеться про опору на той факт, щзо інтуїція є актом, який володіє своӥм об'єктом» [6, 67].

Але чи $є$ «припинення роботи свідомості» Бергсона, яке розуміється нами як його варіант феноменологічної редукції, відмовою від рефлексії, зануренням у дорефлексивність? Бергсон, який у своїх працях висловлювався більш обережно, найбільш відверто пояснює, чим є його інтуїція, у листі до Жака Шевальє 28 квітня 1920 р. У ньому він визнає не лише понадчуттєвість, а й супра-інтеллектуальність своєї інтуїції, якщо під «інтелектом» розуміти сукупність дискурсивних здатностей духу,.. призначених до того, щоб мислити матерію. Інтуїція ж звернена до духу» $[8,21]$.

Бергсон призиває бачити речі «sub specie durationis»: «3 точки зору тривалості». Тому що світ $\epsilon$ не речами й не сукупністю речей чи статичних феноменів, за якими ховаються незмінні ноумени. Це світ триваючий, світ у русі, процесі. У доповіді «Філософська інтуїція» (1911) Бергсон закликає «вийти зі сфери почуттів і свідомості», «повернути наше сприйняття до його джерела» $[14,78]$. Це нагадує редукцію у тому розумінні, яке ми тільки-но інтуїтивно припустили, а саме - розумінні редукції як припинення роботи свідомості й почуттів для того, щоб у справу могла вступити інтуїція. Цікаво, що й гуссерліанець Мерло-Понті, як виявилося, говорить про інтуїцію як про своєрідну бергсонівську «редукцію»: «Інтуїція моєї тривалості - це навчання тому, щоб взагалі бачити. Це принцип, подібний бергсонівської «редукції», що розглядає всі речі sub specie durationis, - називаємо ми їх суб'єктом, об'єктом, чи навіть простором тому, що сприймаючи нашу власну тривалість, ми вже бачимо внутрішній простір, або нарис протяжності» $[18,184]$ (Пер. 3 англ. 
мій. - Автор статті).

Однак така редукція не означає «відмови від рефлексії», що оперує символами й поняттями. Бергсон просто призиває «повернути у зворотний бік звичайний напрямок роботи думки» $[14,117]$ (Пер. 3 фр. мій. - Автор статті). Це означає: замість того, щоб осягати певний процес за його результатами й наслідками, судити про дійсність за ії̈ готовим зовнішнім виглядом, йти від сталих понять, ідей і символів до рухливого й мінливого життя, від загального до конкретного, від форми до реального досвіду - слід навпаки йти від руху, динамічної зміни, конкретної реальності, досвіду, життя до понять. При цьому створюючи «гнучкі» категорії. Слід зупинити роботу раціонального розуму. Для того, щоб, маючи на увазі невимовну повноту живої тривалості, схопленої інтуїцією, узагальнити ії в поняттях.

Саме таке переосмислення редукції ми знайдемо в послідовника Бергсона Е.Мінковського. У «Життевому часі» він застосовує iii у смислі очищення свідомості від мотивів і установок, - для того, щоб пробитися до живої реальності. I перше, що відкриється після такої редукції, - живє «я», яке безпосередньо включене, залучене у життєвий потік, у природній динамізм життя, і яке можна назвати «екзистенціальним суб' єктом». Тобто через себе, а не через відмову від рефлексії й самого «я», розчинення або злиття зі світом - знаходимо зв'язок із цілим буття. Мінковський осмислює інтуіцію Бергсона як відкриття світу зсередини себе, а не як відкриття світу зсередини нього самого через занурення чи вживлення. Не тільки моє «я» знаходиться у світу, а й світ знаходиться в мені. Тобто, редукція повинна розчистити шлях інтуїції і вчасно поступитися їй. Адже, згідно з Бергсоном, Ціле недоступне аналітичному пізнанню.

Подібним чином, Марсель говорить про «вторинну рефлексію», що має відновити втрачене першою, аналітичною рефлексією ціле. У «Онтологічному таїнстві й конкретному наближенню до нього» (1933) він розмірковує, чи не є ця рефлексія, що відкриває перед нами буття (і повертає нас до нього), «інтуїцією буття» $[17,214]$. Але доходить висновку, що інтуїція є поштовхом, «онтологічним занепокоєнням, що змушує рефлексію працювати» $[16,152]$. Вона $\epsilon$ «вимогою чистоти, чи навіть істини» $[16,152]$ (Пер. 3 фр. мій. Aвтор cmammi). Однак сама по собі вона безгласна й безсила. Як голос даймонія, який ми не слухаємо (за порівнянням Бергсона). 
Потрібна вторинна рефлексія, «за допомогою якої думка прагне відновити інтуїцію, що втрачається мірою того, як вона здійснюється» $[16,147]$ (Пер. $з$ фр. мій. - Автор статті).

Це підтверджує нашу тезу про те, що бергсонівська редукція, принаймні у Мінковського й Марселя, на відміну від гуссерлевської, вимагає очищення свідомості не лише від хибних посилок або конструкцій, а й від хибних намірів, самоомани й зазіхань на володіння реальністю. Вона $є$ етичною, екзистенціальною редукцією. Розробка іiі у цьому річищі Г.Марселем і Е.Мінковським потребує подальшого дослідження.

\section{ЛІТЕРАТУРА}

1. Бергсон А. Французька філософія // Могилянські історико-філософські студії. - К. : Видавничий дім «Києво-Могилянська академія», 2008. C.343-389.

2. Бергсон А. Творча еволюція. - К. : Видавництво Жупанського, 2011.

3. Вальденфельс Б. Вступ до феноменології. - К. : «Альтерпрес», 2002.

4. Вормс Ф. Как Бергсон вводит проблему жизни во французскую философию XX века // Логос (философско-литературный журнал). - №3(71). М. : Территория будущего, 2009.

5. Гуссерль Э. Картезианские медитации. - М. : Академический Проект, 2010.

6. Левинас Э. Избранное: трудная свобода. - М. : РОССПЭН, 2004.

7. Лях. В.В. Критика інтуїтивізму сучасної буржуазної філософії. - К.: Наукова думка, 1975.

8. Маритен Ж. От Бергсона к Фоме Аквинскому: очерки метафизики и этики. - М. : Институт философии, теологии и истории святого Фомы, 2006.

9. Марсель Г. Присутствие и бессмертие. Избранные работы. - М. : Институт философии, теологии и истории св. Фомы, 2007.

10. Марсель Г. Ноmo viator. - К. : Пульсари, 1999.

11. Стружевський В. Онтологія. - К. : ДУХ І ЛІТЕРА, Інститут релігійних наук св. Томи Аквінського, 2014.

12. Хайдеггер М. Пролегомены к истории понятия времени. - Т. : Водолей, 1998.

13. Экзистенциальная психология. Экзистенция. - М. : Апрель пресс; Эксмопресс, 2001.

14. Bergson Henri. La pensée et le mouvant. Essais et conférences. - Paris : Les Presses universitaires de France, 1969.

15. Marcel G. En chemin - vers quell éveil? - Paris : Gallimard, 1971.

16. Marcel G. Etre et Avoir I. Journal metaphysique. - Paris : Aubier, Editions Montaigne, 1968. 
17. Marcel G. L'homme problématique. Position et approches concrètes du mystère ontologique. - Nouvelle éd., Paris, Ass. Présence de Gabriel Marcel, 1998.

18. Merleau-Ponty M. Signes. - Northwestern university press, 1964.

19. Minkowski E. Au-delà du rationalisme morbide. - Paris : L'Harmattan, 2000.

20. Spiegelberg G. The Phenomenological Movement. - Kluwer Academic Publishers, 1994.

Зіневич А.С. Феноменологія й онтологія А.Бергсона як джерело екзистениіальної філософії Г.Марселя й С.Мінковского.

У статті зіставляються онтологічна установка Бергсона й гносеологічна - Гуссерля щодо істини й шляхів її пізнання. Виявляється відмінність у розумінні інтуїції, а саме: як супраінтелектуальної - за Бергсоном, і як інтелектуальної - за Гуссерлем, а також тієї сутності (ейдоса), яку вона має схоплювати. Обгрунтовується наявність бергсонівського варіанта «редукції», яка, на відміну від гуссерлівської, здійснюється як припинення роботи аналітичної рефлексії. Досліджуються шляхи переосмислення Е.Мінковським i Г.Марселем інтуїції та редукції як іії умови.

Ключові слова: інтуїція, редукція, рефлексія, екзистенціальне «я», онтологічний поворот.

Зиневич А.С. Феноменология и онтология А.Бергсона как исток экзистенциальной философии Г.Марселя и Е.Минковского.

В статье сопоставляются онтологическая установка Бергсона и гносеологическая - Гуссерля в отношении истины и путей ее постижения. Показана разница в понимании интуиции: как супраинтеллектуальной и как интеллектуальной, и той сущности (эйдоса), которую она призвана схватывать. Обосновывается наличие Бергсоновского варианта «редукции», которая, в отличие от Гуссерлевой, осуществляется как приостановление работы аналитической рефлексии. Также намечены пути переосмысления Е.Минковским и Г.Марселем интуиции и редукции как ее условия.

Ключевые слова: интуиция, редукция, рефлексия, экзистенциальное «я», онтологический поворот.

Zinevych A. The A.Bergson's phenomenology and ontology as a source of G.Marcel's and E.Minkowski's existential philosophy

Our paper compares Bergson's ontological and Hussel's gnoseological position concerning the truth and ways of its cognition. It highlights the difference in understanding intuition - as supraintellectual and as intellectual, and in understanding the essence (eidos), which it is called to grasp. It affirms the existence of Bergson's variant of «reduction», which, unlike Husserl's one, is being realized as a suspension of the work of analytical reflection. Also it outlines the ways of rethinking the intuition and reduction as its condition by E.Minkowski and G.Marcel.

Key words: intuition, reduction, reflection, existential «self», ontological turn. 